\title{
Nonviolence and reconciliation among the violence in Libya
}

\author{
John Braithwaite and Tamim Rashed
}

John Braithwaite, Peacebuilding Compared Project, RegNet, Australian National University (Australia), John.Braithwaite@anu.edu.au; Tamim Rashed, Peacebuilding Compared Libya, RegNet, Australian National University (Australia), st09003788@ outlook.cardiffmet.ac.uk.

State incapacity to ensure security for reconciliation after wars and to stand behind enforcement of reconciliation agreements is a problem. Lessons are drawn from Libya, a country teetering on the precipice of intractable violence. First, a logic of deterrence is that where deterrence is most needed, it is most dangerous. Second, a logic of restorative justice is that where it is hardest to do, it is most important to do. In places like Libya, traditional tribal justice informed by evidence-based restorative justice is imperative to smother sparks that might reignite civil war. It is also important in transitional zones beyond state authority for controlling transnational crime and terrorism. The importance of local restorative justice in peacebuilding is obscured by grand narratives of what wars are about. Beneath the Libyan grand narrative of a democratic revolution achieved by force of arms are muted subsidiary narratives of transition secured through reconciliations.

\section{Foundations}

Participant observation by Tamim Rashed as both an active fighter and peacemaker in Libya since 2011 is one basis for the current analysis. Another is 39 interviews with stakeholders in these events, including political, tribal, military and justice system leaders, undertaken by Tamim Rashed and John Braithwaite, with both participating in almost all interviews, as part of the Peacebuilding Compared methodology from late 2013 to mid-2014. In our Peacebuilding Compared project, peacebuilding and reconciliation are conceived of in the broader rather than the narrower ways these terms are used in the literature (Braithwaite, Braithwaite, Cookson \& Dunn, 2010a, b; Braithwaite, Charlesworth \& Soares, 2012). Peacebuilding is about all stages of building peace; it subsumes more specific concepts like peacemaking, peacekeeping and preventive diplomacy. Reconciliation is also a subset of peacebuilding concerned with bridging the divide between parties who have been in conflict. 
We can see the viewpoint of some restorative justice scholars who think reconciliation is a concept with too little precision (Parmentier and Weitekamp, 2007: 109-144). Restorative justice is one somewhat more precise conception of how to do reconciliation. Most reconciliation strategies have restorative justice elements. It is important, however, according to our approach, to describe a Sulha in Libya as a Sulha, not as restorative justice, notwithstanding its profoundly restorative character (Braithwaite, 2002: 4). ${ }^{1} \mathrm{~A}$ virtue of restorative justice as a methodological tradition is that it values narratives in the words of the stakeholders in a conflict. Fidelity to this means that if stakeholders use the term Sulha in their narratives, it is best to follow that usage. This does not preclude pointing out that a Sulha complies with so many definitional features of restorative justice (as defined in western literatures) that western scholars can learn something fresh about restorative justice by studying Sulhas as Sulhas.

In the next section, we identify broader dangers in grand narratives of what wars are about unless they are complemented with local stakeholder narratives. Then we consider, in turn, three Libyan narratives of partial failure and partial reconciliation success. These narratives show the importance to peacebuilding of constructing a legitimate state and the importance of nurturing traditional restorative competencies beyond the state. Without urgent investment in both, the likelihood of Libya returning to full-scale war is high. Local conflicts also reveal potential for a restorative justice that listens to how local stakeholders reframe the injustice at issue in rape allegations. Libya's conflicts show the limits of deterrence in the very circumstances where deterrence is most needed, and the maximally transformative potential of restorative justice in the very circumstances where restorative justice is most difficult to do.

\section{Beyond grand narratives}

Wars in which thousands are killed and regimes change are big events. The media supply faraway publics with a grand narrative of what the war was about. Usually it is a big geopolitical story, about terrorism, communism, oil, resources, territorial ambition. Even educated people buy a simple narrative because there are so many wars we are expected to understand.

The grand narrative of Libya is that the Gaddafi regime was a dictatorship that supported international terrorism; it was overthrown by a democratic revolution from below enabled by NATO airpower. Not a false narrative. Yet the role of a player like Sudan's President al-Bashir, who hated Gaddafi, is airbrushed from the global narrative because al-Bashir is the first sitting head of state to be indicted by the International Criminal Court (ICC). Among the NATO coalition, Sudan 'provided the biggest military

1 Sulha is often translated as 'reconciliation' in Arabic. In the context of Libya it is a particular ceremony of reconciliation where elders who have listened to the parties declare a settlement in which payment (or payments by different parties) are usually made. 
contribution on the ground' (de Waal, 2013: 376). Sudan had also penetrated Libyan intelligence from 2010, which allowed Sudanese intelligence to locate Saif Gaddafi in the desert. Unlike the NATO powers, Sudan put a battalion plus tanks on the ground in the East in the critical early stages of the revolution, opening up two inland supply routes to get in a large proportion of the weapons and ammunition that the revolutionary fighters needed (de Waal, 2013: 377).

In this essay, we consider the Libyan revolution as a war in which the Tawerghan people were ethnically cleansed by the Misrata Brigade from lands over which Tawergha had won previous legal disputes against Misratan interests. Then we consider an intertribal and organised crime war involving the black Tebu tribe and Arab tribes in Saharan Libya. Next we ponder conflicts that broke out when civilians attempted to persuade the Misratan and other militias to end their military occupation of Tripoli in 2013. Finally, fighting with Al-Qaeda affiliated groups such as Ansar al Sharia is considered. Dominant narratives of the Libyan Revolution being about 'fighting' are qualified by describing processes where nonviolent means, including reconciliations, were used to dissuade elders of towns not to take up arms to resist the revolution, to persuade fighters who had used force to seize control of a space to relinquish that control back to tribal elders. Such conflicts are difficult to manage while a society still has a long way to go in building a legitimate state. We argue that what is required during the transition to a credible state is a search for ways in which strong local societies can compensate for a weak state. In Libya, we indeed conclude that, if we can identify the right elders, resilient peacemaking and restorative justice are possible and imperative.

Contemporary warfare tends to be a complex mix of many local conflicts. Severine Autesserre (2010) has made this point most influentially in relation to the Democratic Republic of Congo. She concludes that the dominant international relations story of what that war was about, and how it started and ended, misses the multitude of local conflicts that predated the war of that grand narrative and that continue in new ways 'postconflict'. Even World War II can be seen as starting with the Japanese invasion and occupation of Manchuria in 1931 and continuing with massive armed resistance to the reimposition of Dutch colonial rule from 1945 to 1947 in Indonesia, and resistance to many other colonial impositions attempted by World War II's winners. Gerlach (2010) points out that Nazi Germany was an 'extremely violent society': beyond the dominant narrative of a holocaust against Jews, the Nazis also exterminated disabled people, communists, intellectuals of other stripes, Roma and more. Fascist violence perpetrated a diverse array of local atrocities and forms of industrial slavery across Europe and North Africa against distinctively local forms of resistance. Overly sweeping narratives of all wars make historical dopes of us.

A common myopia is for the grand narrative to focus on one big injustice that resonates with western publics, suppressing smaller scale injustices against targets for whom western publics have less sympathy. The extermination of communists in Nazi Germany, and of 'communists' by Suharto's Indonesia, even though these were large-scale extermi- 
nations, are cases in point. In the 'Arc of Instability' around Australia in the late twentieth century, the mass media and the scholarly literature alike gave grudging attention to the ethnic cleansing of Chinese that occurred as part of these conflicts. ${ }^{2}$

For every western grand narrative of genocide or ethnic cleansing - the Holocaust, the former Yugoslavia, Cambodia, Rwanda-there are many dozens of very local ethnic cleansings unrecorded in western narratives of war (e.g. search 'ethnic cleansing' in the electronic copy of Braithwaite, Braithwaite, Cookson and Dunn, 2010b, which covers just one short period of the history of one country). There is usually a reluctance to call these acts 'ethnic cleansing' because they do not occur on a national scale. For those who suffer them locally, the burning of homes, the rape of daughters and the killing of sons are just as real because their whole ethnic or religious group flees that local community forever or for a very long time. In the next section we consider Tawergha as a local ethnic cleansing of people of quite low economic and political status, as a corrective to the Amy Chua (2004) frame that ethnic cleansing is about levelling of market-dominant minorities such as Chinese, Jews and Armenians.

\section{Tawergha}

Tawergha is a ghost town 50 kilometres from Misrata. Until the revolution it had some 30,000 black inhabitants. Tawergha has seen human settlement since Roman times and has long been a way station for the slave trade to Europe and the Americas. Tawerghans are sometimes stigmatised as 'slaves no one wanted to buy'. The descendants of those left behind by the slave trade built a solid economy. It included a flourishing port, a date plantation economy and diverse agriculture. The Tawerghan people were nominally liberated from slavery in colonial times, but it was Gaddafi who gave them the full status of citizens of Libya and who invested in developing Tawergha. Most residents fought on Gaddafi's side, but many from Tawergha also fought for the revolution. Loyalist Gaddafi forces attacked the rebel stronghold in Misrata through Tawergha with predominantly

2 Before the civil war in Bougainville, there were Chinatowns in North, Central and Southern Bougainville that are now gone (Braithwaite, Charlesworth, Reddy \& Dunn, 2010a). Chinese were chased almost completely out of Aceh in the long journey of civil war there, as they were in East Timor (Braithwaite, Braithwaite, Cookson \& Dunn, 2010b: 9; Braithwaite, Charlesworth \& Soares, 2012). The period 19961999 saw some anti-Chinese rioting in West Kalimantan, Maluku, North Maluku, Central Sulawesi and even Papua (Purdey, 2006: 219-220). Chinese businesses were targeted by 'levelling' violence, even though they were not the central players in the conflicts. Nothing transpired in the peacebuilding to address the structural driver of the recurrent targeting of Chinese businesses: economic inequality, namely the fact that $80 \%$ of Indonesia's private corporate wealth was owned by Chinese in the late 1990s. The Solomon Islands conflict in its grand narrative is an ethnic conflict between Guadalcanal and Malaita, yet we must not forget that those targeted when Chinatown in Honiara, a quarter of the city, was burnt down in 2006 were Chinese. In all these places, there has been a political conversation about how to advance reconciliation concerning the violence of the 1990s; in none of them has truth and reconciliation concerning violence against Chinese minorities been part of the policy debate. 
black mercenary troops from countries south of Libya. Misratans often misleadingly viewed those attacking them as Tawerghans. Hence at the end of the war the Misrata Brigade totally cleared Tawergha as well as Misrata's Ghoushi neighbourhood, where fourfifths of residents were Tawerghan.

Signs were erected in Tawergha describing the Misrata Brigade as 'the brigade for purging slaves and black skin' (Sunday Telegraph, 11 September 2011). Motorway signs that had Tawergha written on them have been erased, written over with 'New Misrata'. Sunday Telegraph journalist Andrew Gilligan quoted Ibrahim al-Halbous, a Misrata Brigade commander, as saying 'Tawergha no longer exists, only Misrata. ' 'Nigger' is another word we have seen in racist graffiti in Tawergha. Sam Dagher and Charles Levinson of the Wall Street Journal reported on 18 September 2011 that Mahmoud Jibril, the National Transitional Council Prime Minister, effectively endorsed the wiping of the town off the map in a public meeting at the Misrata town hall: ${ }^{4}$

Regarding Tawergha, my own viewpoint is that nobody has the right to interfere in this matter except the people of Misrata. This matter can't be tackled through theories and textbook examples of national reconciliation like those in South Africa, Ireland and Eastern Europe,' he added as the crowd cheered with chants of 'Allahu Akbar.'

The Wall Street Journal story continues:

Now, rebels have been torching homes in the abandoned city 25 miles to the south ... rebels scrawled the words 'slaves' and 'negroes.' 'We are setting it on fire to prevent anyone from living here again,' said one rebel fighter.

Tawerghan elders whom we interviewed alleged that Misrata had long coveted the productive land and the port trade of Tawergha; the war was used as a pretext for grabbing what they justly failed to grab in a 2004 land dispute in the courts. Misratan banks since the war have also systematically refused to give Tawerghans access to the funds in their accounts. Land, homes, livelihoods and cash have all been stolen. Tawerghans who set up accounts in Misrata had their salaries taken off them and kept for Misratan use. Various murderous attacks on Tawerghan IDP (Internally Displaced Persons) camps suggest that Misratans are not just stopping Tawerghans from going back to their lands; they are also actively seeking them out for revenge.

Rape was the emotional issue that drove the refusal of the Misrata Militia to allow the return of the people of Tawergha to their homes. Al Jazeera allowed itself to be used

3 Al-Halbous' article 'Tawergha no longer exists, only Misrata' (13 August 2011), and Gilligan's quoting of it is widespread on the internet (see e.g. http://en.wikipedia.org/wiki/Tawergha). (All websites accessed July 2014.)

4 http://online.wsj.com/news/articles/SB10001424053111903532804576564861187966284? $\bmod =$ WSJ_ World_LEFTSecondNews\&mg=reno64-wsj\&url=http\%3A\%2F\%2Fonline.wsj.com\%2Farticle\%2 FSB10001424053111903532804576564861187966284.html\%3Fmod\%3DWSJ_World_LEFTSecondNews. 
during the revolution to run stories that individuals working on the propaganda and communications side of the revolution confessed to us that they had fabricated. These included stories of aircraft strafing and killing large numbers of peaceful demonstrators, that chemical weapons were to be used to attack Misrata and gas masks issued to Gaddafi's troops, and evidence that Gaddafi fighters of the Libyan military had been issued with viagra to encourage them to mass rape. Another fabrication was that Gaddafi forces had raped 6,000 women, or 8,000, mainly in the battle for Misrata. The 8,000 rapes estimate was widely quoted in the media without evidence, ${ }^{5}$ particularly in the media of rebel-controlled areas of Libya, and was even reported in an official British Home Office publication. ${ }^{6}$ After $\mathrm{Al}$ Jazeera ran these stories, most western media picked them up. The most disgusting coverage was by CNN's Arabic service, which aired video evidence of a most disturbing sexual assault in which we see a visual of a naked, screaming woman being penetrated by a stick (with limited blurring of the image in the CNN Arabic edition, though extensively blurred in the English edition); this sexual assault was filmed in Tripoli two years before the war and may have been a 'porn' video (Ghoil, 2013). The CNN English report says: 'CNN has obtained a copy of a video shot on a cell phone that appears to show a woman being sexually abused. The person who gave the video to CNN says it was on a cell phone that was confiscated from a Gaddafi loyalist.' In some interviews about the rapes in Misrata, leaders of the revolution made specific reference to Tawerghans as the rapists. The criminal-black-man stigmata (Unnever \& Gabbidon, 2011). The revolutionary propagandists whom we interviewed argued that because rape is such an abhorrent crime in Libya, the rape allegations were effective in motivating men to join the fight to remove Gaddafi.

U.S. Ambassador to the U.N. Susan Rice repeated the rape and viagra allegations in the UN Security Council on 28 April 2011 (Charbonneau, 2011). ICC prosecutor Luis Moreno-Ocampo stated on 8 June 2011 that he might request a new charge of mass rape against Gaddafi following the surfacing of this 'evidence." Anna Louie Susman in The Atlantic (26 May 2011) opined, 'Is anyone surprised?', comparing rape in Misrata to the rape of Nanjing. The Times is widely quoted on the internet as reporting the fabrication from Misrata that 'four sisters were systematically raped by a group of soldiers from Tawurga ... The rapes [by Tawergans] were always brutal, sometimes fuelled by Viagra apparently handed out to Gadhafi's men, sometimes simply by the desire to punish and humiliate.' This was actually never published in the Times as far as we can see. It was written on a blog on the 'Raped by Soldiers' website ${ }^{8}$ by Hala Jaba, who works for the

5 e.g. Reuters, 26 November 2011, http://uk.reuters.com/article/2011/11/26/uk-libya-rape-idUKTRE7AP0F4 20111126.

6 www.bia.homeoffice.gov.uk/sitecontent/documents/policyandlaw/countryspecificasylumpolicyogns/ libya-ogn?view=Binary.

7 www.france24.com/en/20110609-libya-gaddafi-linked-systematic-rape-opposition-says-icc-prosecutorocampo.

8 http://couchtripper.com/rapedbysoldiers/?m=201104. 
Sunday Times, on 18 April 2011. Two captured pro-Gaddafi soldiers from Tawergha were later produced to the media to confess to the rape of the four daughters. Amnesty and UN investigators interviewed them and concluded that these confessions were fabricated and coerced by torture. ${ }^{9}$ The Daily Mail of 31 August 2011 and other western papers went a step further, alleging that 'A father slit the throat of his three teenage daughters in an "honour killing" after they were raped by Gaddafi loyalists during the siege of the port city of Misrata' - another sensational story which no subsequent investigation supported. ${ }^{10}$

Quantitative social science research on an impressive sample of 60,000 women (a truly formidable sample for a country of 7 million people) with an unprecedented response rate also became part of a tidal wave of evidence:

Seemingly the strongest evidence for mass rape appeared to come from a Libyan psychologist, Dr Seham Sergewa, who says she distributed 70,000 questionnaires in rebel-controlled areas and along the Tunisian border, of which over 60,000 were returned. Some 259 women volunteered that they had been raped, of whom Dr Sergewa said she interviewed 140 victims.

Asked by Diana Eltahawy, Amnesty International's specialist on Libya, if it would be possible to meet any of these women, Dr Sergewa replied that 'she had lost contact with them' and was unable to provide documentary evidence. (The Independent, 24 June 2011)

United Nations investigators concluded that this was one of the most logistically impressive accomplishments in the history of social science, to get 70,000 questionnaires out to people in March 2011 when the mail service in Libya was not functioning and then get the data analysis done in about a month. The United Nations put considerable resources into attempts to find these 259 rape victims and others. Cherif Bassiouni, who led a UN rights inquiry into the situation in Libya, suggested that the claim was part of a 'hysteria' after he was only able to find three possible cases of rape during the revolutionary war. ${ }^{11}$ Further investigation since 2011 confirmed more than three cases, though far fewer than 20-fewer than countries of this size would expect to suffer in times of peace.

On the very day that Ambassador Rice made her rape allegations to the Security Council, Uri Freidman ran a story on The Wire quoting a Human Rights Watch consultant on the ground who had learned of 'a few credible cases of gender-based violence and rape, but the evidence is not there at this point to suggest it is of a systematic nature, or

9 'When the Misratans interrogated alleged perpetrators they would say to them how many women did you rape? They might say 6 to escape torture. If this did not seem like enough to satisfy their interrogators they'd go up to 10. One of them satisfied their interrogators by showing houses were they had done it. When I spoke to prisoners they said in conditions of confidentiality that they had been tortured to provide these admissions.' (Human rights worker interview Tripoli, 2013.)

10 www.dailymail.co.uk/news/article-2031710/Libya-Father-slit-throats-girls-raped-Gaddafis-men.html.

11 'Libya rape claims hysteria-Investigator', AFP, 10 June 2011. 
an official policy. On Viagra and condom distribution we have nothing so far. ${ }^{12}$ After extensive investigations since then, that remains the basic finding of Human Rights Watch, Amnesty International and the United Nations Rule of Law and Human Rights gender specialists. The ICC and human rights groups' investigations in Misrata have failed to document even six cases of gender-based violence during the revolution, let alone 6,000 in Misrata, and most of the few credible allegations that might be provable do not involve Tawerghan fighters.

It was not the ICC's finest moment when it failed to apologise for the recklessness of the trial by media of its then prosecutor in relation to mass rape being ordered by Gaddafi as a weapon of war. Amnesty's senior response adviser, Donatella Rovera, who was in Libya for three months after the start of the uprising, did attempt to set the record straight, saying, 'we have not found any evidence or a single victim of rape or a doctor who knew about somebody being raped' (The Independent, 24 June 2011). Likewise, Liesel Gerntholtz, head of women's rights at Human Rights Watch, which also investigated the charge of mass rape, said: 'We have not been able to find evidence' (The Independent, 24 June 2011). There is, on the other hand, clear video evidence, in which the face of the perpetrator is clearly visible, of the rape of Gaddafi by repeatedly inserting a stick into his anus; blood issues from the anus; he was also penetrated by the nozzle of a Kalasknikov and possibly a bayonet; Gadaffi, the very man the ICC Prosecutor argued should be charged with rape, seems to have been raped in vengeance before his death alongside his bodyguards and family members.

The ICC Office of the Prosecutor now has an obligation to go public in correcting the reports of mass rape as a weapon of war, which it now knows to be false, that motivated the ethnic cleansing, illegal detention and alleged murder of supposed Tawerghan rapists. Two and a half years on, hundreds of Tawerghans are still imprisoned in private prisons run by the Misrata Militia. Amnesty (2013) estimates that 1,300 Tawerghans have been detained or disappeared. The Tawerghan Council alleged to us that some Tawerghans had been released from prison in Misrata on the basis of bribes. Others were released on condition that they would go to fight in Syria; when they arrived in Syria they were told they would never be allowed to return to Libya - not so different from the way black slaves were used in wars of centuries past. 'Some Misratans allege that the majority of the jailed Tawerghans are rape perpetrators. One even said 99 per cent' (Human rights worker interview, Tripoli, 2013). We interviewed a number of Tawerghan prisoners who had got out. They alleged many extra-judicial assassinations, many deaths in custody, torture of the majority of Tawerghan prisoners and rape of prisoners as retribution for their supposed rapes, as did some human rights workers we interviewed. These men were allegedly murdered, raped and tortured in part as a result of the infidelity of the

12 www.thewire.com/global/2011/04/americas-un-envoy-says-qaddafis-giving-viagra-his-troops/37159. This includes the original less than convincing source-the Al Jazeera story of 27 March 2011, www. youtube.com/watch?v=ISLz8Fv0eik. 
then Prosecutor of the International Criminal Court to criminal law values. The way to put this right is for the Office of the Prosecutor to take the restorative justice path, to put right its wrong by naming the illegal imprisonment, torture and execution of soldiers who fought in the former Libyan army as war crimes that were partly motivated by false allegations of mass rape by the Office of the Prosecutor. The problem is that the Office of the Prosecutor may not believe in restorative justice values, or in prosecutors taking responsibility for their wrongdoing.

This is a hard case because Misratans are convinced that they have been victims of mass rape that has been vindicated by 'real evidence' such as confessions they see on the media, social scientific research and vindication by authoritative international officials who are supposed to be expert in sifting evidence dispassionately. Misratans have been disposed to interpret female suicides and illicit pregnancies that occurred during this chaotic period as a result of rapes, more disposed than the detailed investigations of the $\mathrm{UN}$ and the human rights organisations would suggest is justified. It is difficult to see reconciliation happening without a large dose of truth, or at least reasonable doubt, first. International leadership in accepting responsibility for an inconvenient truth could catalyse national truthtelling, laying a foundation for the Misratan militia to comply with the laws of war. That might lay a further foundation for third-party tribal wisemen to broker reconciliations between Misratan and Tawerghan tribal elders. On the Tawerghan side, it might require Tawergha's cooperation and testimony to lay criminal charges against every single Tawerghan against whom prosecutors with special funding and training from donors could find evidence of war crimes of any kind.

This is an important reconciliation for the future of Libya because most of the remaining IDPs in the country are from Tawergha. All attempts by them to return home have been thwarted by the threat of overwhelming force against them. Crimes against humanity are ongoing against Tawerghan prisoners and must be stopped. Reconciliations have succeeded between other towns that were at each other's throats during the war, for example between Zintan, which was on the side of the revolution, and Al-Riyaina, which was loyal to Gaddafi, in October 2013. This case suggests that rape can be a crime where restorative justice approaches have relevance in empowering stakeholders to reframe the injustice. It also shows a need for the International Criminal Court to be called to account to face restorative justice for the injustice it caused in the way it alleged rape in war.

\section{Small town wars between Tebu and Arab tribes in Sebha}

One thing we often say in lectures on restorative justice is that we have not seen a case, or heard of a case from the work of other restorative justice researchers, where angry words in restorative justice conferences have escalated into physical harm to a person. This is remarkable, because the stakeholders are generally extremely angry about the matters 
being dealt with. The explanation, we argue, is that even the worst of us, even the most violent among us, have multiple selves. The restorative justice conference is a strategy that coaxes us to put our best self forward.

We always winced a bit as we made this claim. We wondered if some of our practitioner colleagues really had restorative justice cases that had spun into violence, but decided not to mention them because this was hardly a great accomplishment. The day might come, we thought, when someone would jump up and say they knew of cases where violence had broken out in conferences! Though no one has put their hand up to contest our claim until now, a good methodological prescription is to keep searching for the deviant case so that its theoretical implications can be fathomed.

Now we have finally found a case where extreme violence broke out in a process that we would call restorative. It was a reconciliation between the Tebu tribe living in southern Libya (most Tebu live in northern Chad, but also in northeastern Niger and northwestern Sudan) and Arab tribes in Sebha (southern Libya) in March 2012. The inter- and intra-tribal reconciliation traditions in this part of the world have been described as fully restorative (McCold, 2000) in the past (e.g. Braithwaite, 2002: 4). These Islamic tribes follow the pre-Islamic, pre-Christian traditions of the Sulha (Jabbour, 1997) that were probably widespread across the ancient worlds of the Middle East and the Maghreb of North Africa. They were traditions that Jews and Christians also long used in conflicts with Muslims in Galilee.

The reconciliation at issue was unusually geopolitically important. During the Libyan Revolution of 2011, many Tebu who were stateless in Libya were promised citizenship by Gaddafi if they fought for him. Both before and after the revolution, other Tebu claim that promises of future Libyan citizenship were made in return for specific kinds of service such as providing security for oil production facilities. ${ }^{13}$ Tebu leaders complain that they have been constantly harassed and attacked by Arab militias since the fall of Gaddafi.

One response of Tebu militias has been to march into oil production facilities in the south of Libya, where most oil is to be found, ordering at gunpoint that plants be switched off. Early reports that Libyan oil production had returned to pre-conflict levels (Vandewalle, 2012: 14) have reversed at the time of writing, with production still falling and variously estimated at between 20 and 50 per cent of pre-conflict levels. Sebha has always been a rather lawless frontier town. In centuries past Sebha was on a caravan route across the Sahara where African slaves were traded north. Sebha is still a conduit for human and drug trafficking in the north and gun smuggling in the south, as well as

13 A Tebu leader, Younis Essa, a 'revolutionary and member of Ahmed Al Sharif Brigade tasked with the protection of oil fields' argued that when the 2011 uprising against Gadaffi started, most Tebu were on the side of the revolution. Gadaffi promised to revoke a 1996 decree that had left Tebu from the border area between Chad and Libya stateless following a border war. This was an effort to persuade Tebu to support him that did not dissuade Tebu from fighting for the revolution. 
various other kinds of cross-Sahara smuggling. Members of two tribes have fought for the domination of organised crime in Sebha, Tebu militias and the Arab militia of the Awlad Sulayman tribe. The conflict started between the Tebu and another Arab community with whom the Sons of Sulayman militia sided.

The reconciliation of 26 March 2012 was convened in the traditional way, conducted by mainly Misratan wisemen of tribes who were not involved in the original conflict. The tribes involved in the conflict were the Tebu, the Awad Sulayman and the Abu Saif. We heard various disputed versions of the initial spark of conflict, but it seems likely to have been the killing of an Abu Saif member by Tebu carjackers. A firefight broke out during heated argument at the preliminary ('understanding') phase of the reconciliation process in the 'People's Hall'-long before the desired reconciliatory Sulha outcome was approached. Three Sebu were killed inside the reconciliation meeting. The Tebu then took the fight onto the streets of Sebha. In no time fighting had escalated to what van Klinken (2007) has called a 'small town war'. According to some estimates, at least 147 people were killed and 500 wounded (International Crisis Group, 2012: 7). The Tebu took control of the airport, presumably to prevent military aircraft from flying in troops, and also seized control of the hospital to ensure that the needs of their wounded were not neglected. Ultimately, however, the other normally rather disunited tribes in Sebha united to get on top of the Tebu fighters with heavy shelling of Tebu shantytowns that were attacked by tanks and Katusha rockets. This shelling put an end to Tebu mortar fire into Awlad Sulayman neighbourhoods of Sebha.

Overwhelming military capacity rested with the Awlad Sulayman; in February 2012 they paraded 50 tanks and scores of 'Grad' missiles through Sebha (Pelham, 2012: 544). Then there was a slightly more successful reconciliation process, tearful and heavy with apologies, again conducted in the traditional way by wisemen with little support from the state. It produced a ceasefire. This was broken at various times by both sides because of the lack of state capacity to enforce it (International Crisis Group, 2012: 28-34) and because only a ceasefire had been accomplished, not full reconciliation. That is, the process did not move from the understanding phase, to ceasefire, to settlement of root causes, to the reconciliation rituals of the Sulha-the killing of sheep in honour of one's adversaries, breaking bread and saying of prayers together. The ceasefire did succeed in ending conditions approaching all-out tribal warfare until January 2014, when serious fighting flared again. One might argue that the failure to prevent stakeholders from bringing weapons into the March 2012 reconciliation was less a failure of the mediators than a failure of state policing capacity to prevent participants from entering the room with guns for such an important event.

Of course the policy prescription that comes from this story is a rather banal one: it is not a good idea for stakeholders to carry guns into restorative justice conferences. The context here is interesting, however. Sebha has always been a place with a gun culture. In one meeting with four women's leaders of Sebha, one of the women surprised us by 
saying that ironically gun violence had reduced in Sebha because it had moved from a place where only some could dominate because they owned the guns to a world where everyone was afraid of provoking everyone else because everyone has guns. A practical implication of her point is that in this atmosphere of mutual fear and preparedness for violence it would be difficult to run a reconciliation process that kept guns out of the room. Others seemed to agree with her analysis.

The March 2012 and January-February 2014 small town race wars show the limits of this analysis, however. International relations theorists have proffered a similar analysis about nuclear weapons and the absence of war between NATO, Russia and China since World War II. With nuclear weapons war became too dangerous for rational states to countenance. The folly of this analysis based on a sample of three national adversaries is illustrated by the behaviour of nuclear-armed India and Pakistan, who may have suffered the implications of exactly the reverse of this analysis (Snyder, 1965). Pakistan believed it could push the envelope with conventional warfare and terrorism in Kashmir because India would not let retaliation go too far for fear of a nuclear exchange. India and Pakistan have fought five minor conventional wars over Kashmir since World War II. Imagine the accidental disaster where the nuclear trigger is pulled unintentionally, where reaching for a weapon is misinterpreted as an imminent threat. Imagine the large nuclear state equivalent to the small town war of the Tebu versus the Arabs.

Mutually Assured Destruction (MAD) can be the alternative to reconciliation in the contexts where it is hardest to make reconciliation work. Yes, maximal armament can achieve a kind of terrorised deterrence, even for quite a long period, as with the Cold War (though with proxy wars in Africa, Asia and Latin America). The logic of deterrence is that where it is most needed, deterrence is most dangerous. Deterrence is most needed if the threat faced is mass destruction, but if that needed deterrent is Mutually Assured Destruction, then the deterrent is maximally dangerous. The logic of restorative justice is that where it is hardest to do, it is most important to do. Restorative justice is hard to do when factions feel strong in their positions because they are powerfully armed. Yet because deterrence involves risky escalation in that context, this is where restorative justice is most important to do. Nelson Mandela's life was testimony to the challenge that where restorative justice is most institutionally difficult to do, it is most important to do. And that restorative justice can happen to an important degree in conditions of extreme violence and tyranny.

This small town war broke out again on 9 January 2014 as a result of the failure to achieve a genuine reconciliation in 2012. It started in earnest when Tebu gunmen stormed a Traghen police station south of Sebha. High value targets were ignored as they searched specifically for al-Haq Brigade leader Mansur al-Aswad. The brigade leader was murdered, allegedly in retaliation for crimes committed by his Abu Saif militia during the 2012 clashes in Sebha (Libya Herald, 10 January 2014). In January 2014 at least 88 people were killed in the renewed fighting. One pro-Gaddafi group seized the opportu- 
nity created by the lawlessness to take over Tamenhint airforce base 30 kilometres east of Sebha, leading to much speculation of outside influence, possibly from Gaddafi family exiles, to destabilise the south through the Sebha tribes. This gave the small town war a new national character, triggering mobilisation of the military and the Misrata Militia to return control of the airforce base to the state. In another southern Oasis town where fighting occurred between Tebu and Arab tribes, Isa Abd al-Majid, leader of the Kufra Tebu fighters, warned: 'We are fighting al-Qaeda. They want to eradicate us to occupy our land and control the frontiers with Chad and Niger, which will permit them to attack the French military base in Niger and kidnap Westerners' (Paris Match, 20 January 2014). So from the two sides, two very different narratives of international destabilisation are advanced, one about Gaddafi, the other about Al-Qaeda.

The Sebha response to the renewed crisis has been a creative one, to invite leaders of the Zintan militia headed by Mohammed Imbisher to be trusted third-party mediators to conduct a new reconciliation process. The government is represented in the reconciliation at a high level through the Justice Minister Salah Bashir Al-Marghani, Labour Minister Mohamed Fitouri Sualim and Head of Intelligence Salem Al-Hassi. What is interesting about this is that the Zintan Militia was one of the two most militarily powerful militias of the Libyan revolution that ousted Gaddafi. It is the militia that still holds Saif Gaddafi in its private prison. The Zintanis retain in many ways a more formidable security capability than the Libyan state. So the hope is that they might have the authority, the 'street cred' and the deterrence capacity to ensure that no one shoots at anyone in a reconciliation conducted under their authority. As this paper goes to press, it remains to be seen whether this beautiful theory might also become an ugly practice, or might succeed. At least the commencement of the reconciliation process has temporarily suppressed fighting in mid-2014.

\section{Misrata militia domination of Tripoli}

Our next case of partial success in mediating a peaceful path in the midst of violence relates to the Misrata Militia, who played a major role in the liberation of Tripoli. To the consternation of locals, they stayed, causing many security and crime problems, including punitive attacks on the large Tawergan IDP camps in Tripoli. On 15 November 2013 unarmed citizens marched toward the Misrata Militia compound in Tripoli, protesting their domination of the city. The militia opened fire on the crowd with anti-aircraft weapons mounted on pick-up trucks. High calibre rounds ripped limbs and heads off the bodies of the crowd as they passed right through it. Approximately 43 were killed and 460 wounded according to the Ministry of the Interior.

The nonviolent sacrifice made by these victims, rather than any military or police threat to drive the Misrata Militia out of Tripoli, was the decisive factor in the militia deciding to leave soon after. As Hashim Bishr, then head of the Tripoli Supreme Security 
Committee, put it: 'It was the public uprising against them that could beat any militia. It was the people rising up in mass against them that could get them out. Force could not do it' (December 2013 interview). For some time, Tripoli elders, government leaders and third-party tribal leaders had been attempting to persuade the Misrata leadership to quit Tripoli, to hand over 80 tanks in their possession to the state military, and much more. These peace negotiations took large steps forward after the nonviolent sacrifice by those hundreds of citizens on the streets of Tripoli.

There were also many comparable examples of mediated negotiation of a peaceful path during the revolution. This included the fall of Tripoli itself. The revolutionary military leadership and NATO expected a bloody six-month battle for Tripoli. Instead, a combination of the revolutionary forces approaching the city supported by NATO air power, dialogues within the city about the virtue of pro-Gaddafi elements defecting from the regime, and ordinary people massing out onto the streets in huge numbers on 20 August 2011, created a nonviolent momentum in the city that combined with military pressure looming from the suburbs. This caused almost all pro-Gaddafi loyalists huddled in the capital to defect, run or surrender, though there were pockets of fighting that were extinguished by the revolutionary brigades within a few days. As Hashim Bishr, rebel commander for the liberation of Tripoli, put it: 'The population rising was the key. Gaddafi's people flipped overnight to defect from and desert the regime' (Tripoli interview, 2013).

The international image of the Libyan revolution is of a result achieved by military means. This is a partial truth about a more complex reality. Beyond Tripoli, there were other towns where in advance of rebel attacks on them, tribal elders inside the town were persuaded by third-party wisemen to take their people into a peaceful embrace of the revolution. The local elders then persuaded their tribe members in the military to either defect or stay at home, allowing peaceful takeover of the town. Examples were small towns and villages around Benghazi during the early stages of the revolution, including Az-Zawiya and Mizdah. Our interviews suggest that many towns were not aware of what was going on during the revolution and elders used opportunities such as fleeing Benghazi for surrounding towns when Benghazi was under attack to inform people in those surrounding towns that the revolution was gaining momentum, building their support to embrace the revolution. In one account of negotiations in September 2011 with over a dozen tribes between Ras Lanuf and Sirt which had been mostly pro-Gaddafi, Hafiz (2011) reported the importance of gifts of food, medicines and water to lubricate a peaceful transition and reconciliation:

It hasn't been easy to break bread with the enemy, but here the revolutionary forces try everything to avoid conflict with tribes loyal to Gadaffi ... Despite the tribes reluctance to support the revolution and their backdoor dealings with Gadaffi's army, revolutionary fighters bring food, water and medicine to this tribe daily. Revolutionary leaders explain the need to continue negotiations even as the battle for Libya rages. 


\section{Reconciliation with Al-Qaeda affiliated groups}

Processes not dissimilar to those that persuaded the Misrata Militia to quit Tripoli have also been used to persuade Islamist groups affiliated with Al-Qaeda, such as Ansar al Sharia, to leave cities. Derna and Benghazi are the heartlands of Libya's most dangerous Islamist group today, Ansar al Sharia, where they have been able to parade openly in public squares flying the black Al-Qaeda flag. Tribal leaders have persuaded Islamist groups such as Ansar al Sharia to leave cities including Sebha, Al Bayda and Al Marj, with mediated negotiations and sometimes a threat of force in the background. The methods used to ensure that the Islamist groups did not entrench in their towns varied slightly, but the main factor was the use of the tribal culture mediated through elders and wisemen. Tribal elders and wisemen of Al Bayda and Al Marj made it clear to tribal members of the town that anyone who decided to join certain Islamist groups would be disowned by their tribe immediately. This message was mainly communicated through council meetings and talks at the local mosques during Friday prayers. This method was carried out early on, ending brainwashing of their members in those towns before it started in earnest.

In the case of Sebha, tribal members of the town did start to join these Islamist groups through recruitment processes using the schools and mosques. However, tribal elders and wisemen of Sebha started to realise this and began to make examples of those members by either arresting them, or their families, and removing them from the town, which is seen as a very shameful situation to be in, especially in the southern culture of Sebha (Sebha leader interview, February 2014). Tribal methods for driving Al-Qaedaaffiliated groups out of towns have been only a partial accomplishment for consolidating peace, as Islamist groups have moved to the mountains and deserts outside the towns where the jihadists run training camps that have fed the Salafist terror groups in Iraq and Syria (where many more than a thousand Libyan fighters exported from such training camps into Syria have been killed). Reconciliation between the Libyan mainstream and those exiled Salafist fighters is imperative. The people to do it are radical Islamist leaders and wisemen who nevertheless believe that nonviolence is the right path for Islam and that jihadist exiles must be reintegrated into mainstream Libyan society. Rebel commander Hashim Bishr, who himself was a radical Islamist, argued that Ansar al Sharia will not reconcile at the behest of most tribal leaders. He argued that there are only half a dozen leaders they would listen to, who they would see as genuinely committed to Sharia law and beyond capture by the west.

Radical Islamist revolutionary commanders who have converted to nonviolence like Hashim Bishr are important because there are peacemaking positives to build upon among the more radical Islamist groups. Many of their leaders have succeeded in significant ways in reducing violence. One group-the Army of the Islamic State of Libya, led by Yousef Ben Tahir-have the ideology to bring safety to the town of Derna based on Islam. In an interview with Mathieu Galtier (2013), Yousef Ben Tahir stated: 'Our 
goal is simple: implementing security in public buildings, on the streets and for private companies. First in Derna, then in other cities like Benghazi and Sirte, and finally in all Libya-because Islam says it is our duty as Muslims to protect people.' This aspect of their goals corresponds with those of the government. Benghazi saw a turn of events with security in places such as the Al Jalaa Hospital. Residents used to complain about the lack of security provided by the Saiqa Brigade and drunk and drugged people threatening security around the hospital gates, as well as violent incidents inside the hospital. Ansar al Sharia took up the security challenge there. The response from locals suggests that it was a positive outcome. ${ }^{14}$ They completely removed the drunk and drugged people from the area, which eradicated other crime and insecurity problems. They have restored security to a high standard and in a professional manner. Sirte is another place where Ansar al Sharia have been mediators in tribal conflicts that erupted between the Qadhadhfa tribe and the Misratans living in Sirte. The Sirte Local council credited Ansar al Sharia for its work in helping to contain the violence.

All over the world, radical Islamists build support for their cause by providing security to people who crave it. The peacebuilding challenge is to harness this as a positive part of a transition to Islamist support for nonviolence (rather than as a foundation of legitimacy for future campaigns of violence). The key actors in this are the Hashim Bishrs who have already made that transition. In a context where all political factions in Libya agree with Sharia law as a foundation of the new Libyan state and constitution (though with different shades of intensity), where all disapprove of bars that sell alcohol, brothels, and other western influences that inflame Salafists in other Muslim societies, it may not be an impossible reconciliation challenge to secure renunciation of terror and embrace the opportunity to participate democratically in advocacy for incorporating Sharia law into Libyan governance.

In an interview with a parliamentary and oil industry leader, there was confidence that 2014 would see a national dialogue all over Libya:

Five to seven leaders will be appointed from every area, making 465 to 91 leaders that will constitute a second chamber of the parliament like a House of Lords. They will call it something like that. The elderly elites of the provinces. This House of Lords will initiate dialogues with militants, tribes, etc. They will use both tribal and Sharia traditions, especially Sharia traditions when they are religious leaders. But the tribal leaders will do most of the work. The

14 See Maha Ellawati in the Libya Herald (4 October 2013) on the failure of the state to provide security: 'Employees of Jalaa hospital in Benghazi have protested for a third day about the lack of security at the hospital and demanded the return of Ansar Al-Sharia personnel. Medical staff have said that since Ansar Al-Sharia security guards left, the hospital has been suffering from security problems all the time. A female doctor said that medical staff are being verbally and even physically assaulted on a daily basis. Another doctor described how the grieving friend of a man, injured in a road traffic accident, went on the rampage after learning that doctors had been unable to save his friend's life ... A doctor said: "We are subjected to this kind of abuse on a daily basis and that is why we are now demanding the provision of security for us, and in particular Ansar Al-Sharia." ... There have also been reports of patients and visitors bringing weapons into the hospital and firearms being used to threaten doctors and nurses.' 
House of Lords will work on arms surrender as the first priority. Then the second priority will be reconciliation all over Libya. (Tripoli interview, December 2013)

In the meantime, experienced peacemaking NGOs like Humanitarian Dialogue are doing useful work in encouraging elders from different sides to enter peace dialogues. This is the helpful and restorative kind of international assistance. Le Figaro reported on 1 February 2014 that elite US Delta Force Commandos are fighting alongside Libyan commandos attacking Al-Qaeda militants in the south of Libya. The Libyan government says this is not true (World News, 3 February 2014). The government of Libya is wise to want the international community to limit its counterterrorism support to technical assistance with reconciliation, leaving last resort armed enforcement of the rule of law to domestic forces.

\section{Conclusion: Restorative justice, peace and transnational crime threats}

One way of seeing the restorative justice contribution to peacemaking is to promote a politics of hope about truth and reconciliation. Chenoweth and Stephan (2011) diagnose cases like South Africa and Timor-Leste as civil wars where leaders such as Nelson Mandela and Xanana Gusmao saw that moving the strategy of resistance from primary reliance on armed struggle to primary reliance on nonviolent resistance could work. We can also see a case like Nepal's transition to peace, democracy and its overthrow of the monarchy in this way. When the Maoists announced a unilateral ceasefire in 2006 and their intent to work with the other political parties towards democratic elections and a democratic constitution, the people of Nepal massed onto the streets of Kathmandu and other Nepalese cities, joined general strikes to support the Maoist transition to peace, and demanded that the king step aside to make way for democracy. This led to the Comprehensive Peace Accord of 21 November 2006.

Where does this leave us when a reverse dynamic is in play, as in Syria, where nonviolence on the streets fails to secure sufficient defections from the regime for regime change, and where, as a result, civil war and Islamist terror displace nonviolence? The leadership of the Carter Center had an interesting answer when we put this question to them in November 2013. They said that in Syria, while it was not possible to push forward with a national peace process and national reconciliation during 2013, it was still possible to work on local ceasefires that save lives and create a few 'islands of civility' (Kaldor, 1999) from which peace might eventually be given a chance to spread.

In summary, then, restorative processes such as tribal Sulhas in Libya have a role in building peace hot-spot by hot-spot even as national peace and reconciliation remains elusive. Restorative principles and insights from evidence-based restorative justice have something to offer at the level of many micro reconciliations that can gradually build a base for national reconciliation. Community-level peacemaking can help a state like Libya, that has not yet been built, to survive and strengthen during the first five years 
after a civil war, when the statistical prospects of another war are 50/50. Communitylevel peacemaking helps that survival by smothering local sparks of conflict before they become a wildfire.

The failure of the west in Libya is similar to its failure in Afghanistan after the Soviets were forced out in 1989. Instead of working to support an imperfect Sharia-oriented transitional government to gradually build on the state institutions that remained, to improve state education infrastructure for girls that the communist regime had built for the Taliban to later dismantle, the west walked away from support for an imperfect transition and left the game to competing mujahedeen and Pakistan's intelligence service to trash remaining state institutional infrastructure. This continued until the Taliban marched to power to impose a pathological form of law and order that became a profound threat to the west.

The French have dispatched troops to Mali to contain the jihadists who gained ascendency with mercenaries and heavy weapons trafficked through Sebha because of failures to offer reconciliation and life opportunities to unemployed young jihadists as unemployment makes them a target for Al-Qaeda-affiliated recruiters in certain mosques and schools. In the badlands of the south of Libya where state control is absent, a lawless vacuum has attracted large swathes of control by Tebu organised crime groups and pockets of Al-Qaeda control, both of which are profound transnational crime threats. Of course, gradual building of the authority of a new democratic Libyan state in such anomic spaces is imperative for reducing these threats. Had state security been able to insist that disputants leave their guns at the door for the March 2012 Sebha reconciliation meeting where shooting broke out, this spiral of violence may have been nipped in the bud. But assertion of state authority in southern Libya is certain to be gradual and contested. In the meantime, the hope for human security for the frightened people of Sebha and across Libya is traditional tribal reconciliation by trusted wisemen. In time, wise women can come to sit with them, but only where islands of civility are secured to give women's voices a chance of being heard. ${ }^{15}$ The worse the violence is, the more important reconciliation that gradually displaces guns becomes.

$1571 \%$ of Libyans agree that ' $\mathrm{t}$ ] he participation of women in political life has not yet reached a satisfactor[il] $y$ high level', and $61 \%$ agree that ' $[w]$ omen elected with the help of gender quotas are qualified to hold office' (National Democratic Institute, 2013: 34). 


\section{References}

All websites accessed July 2014

Amnesty International (2013). Two years after conflict Libya must end plight of displaced persons, www.amnesty.org/en/for-media/press-releases/two-years-after-conflict-libya-must-endplight-displaced-communities-2013-1.

Autesserre, S. (2010). The trouble with the Congo: local violence and the failure of international peacebuilding. Cambridge: Cambridge University Press.

Braithwaite, J. (2002). Restorative justice and responsive regulation. Sydney and Oxford: Federation Press and Oxford University Press.

Braithwaite, J., Charlesworth, H., Reddy, P. \& Dunn, L. (2010a). Reconciliation and architectures of commitment: sequencing peace in Bougainville. Canberra: ANU E-Press.

Braithwaite, J., Braithwaite, V., Cookson, M. \& Dunn, L. (2010b). Anomie and violence: non-truth and reconciliation in Indonesian peacebuilding. Canberra: ANU E-Press.

Braithwaite, J., Charlesworth, H. \& Soares, A. (2012). Networked governance of freedom and tyranny: peace in Timor-Leste. Canberra: ANU E-Press.

Charbonneau, L. (2011). US envoy: Gadaffi troops raping, issued Viagra, Reuters (29 April), www. reuters.com/article/2011/04/29/us-libya-troops-rape-idUSTRE73S74B20110429.

Chenoweth, E. \& Stephan, M. (2011). Why civil resistance works: the strategic logic of nonviolent conflict. New York: Columbia University Press.

Chua, A. (2004). World on fire: how exporting free market democracy breeds ethnic hatred and global instability. New York: Anchor Books.

de Waal, A. (2013). African roles in the Libyan conflict, International Affairs, 89, 365-379.

Galtier, M. (2013). The army of Islamic State of Libya: Derna's mystery militia. Libya Herald (7 November), www.libyaherald.com/2013/11/07/the-army-of-islamic-state-of-libya-dernasmystery-militia.

Gerlach, C. (2010). Extremely violent societies: mass violence in the twentieth-century world. Cambridge: Cambridge University Press.

Ghoil, D. (2013). Book Review-slouching toward sirte: NATO's war on Libya and Africa by Maximilian Forte, www.mathaba.net/news/? $x=633041$.

Hafiz, J. (2011). Revolutionary commanders in talks with tribal leaders loyal to Gaddafi. Press TV (18 September), http://presstv.com/detail/199876.html.

International Crisis Group (2012). Divided we stand: Libya's enduring conflicts: Crisis Group Middle East/North Africa Report No. 130 (14 September). www.crisisgroup.org/en/regions/middleeast-north-africa/north-africa/libya/130-divided-we-stand-libyas-enduring-conflicts.aspx.

Jabbour, E. (1997). Sulha: Palestinian traditional peacemaking process. Montreal: House of Hope Publications.

Kaldor, M. (1999). New and old wars. Stanford: Stanford University Press.

McCold, P. (2000). Toward a holistic vision of restorative juvenile justice: a reply to the maximalist model. Contemporary Justice Review, 3(4), 357-369.

National Democratic Institute (2013). Seeking security: public opinion survey in Libya, www.ndi. org/node/20905.

Parmentier, S. \& Weitekamp, E. (eds.) (2007). Crime and human rights. Amsterdam/Oxford: Elsevier. 
Pelham, N. (2012). Libya in the shadow of Iraq: The 'Old Guard' versus the Thuwwar in the battle for stability. International Peacekeeping, 19, 529-548.

Snyder, G. (1965). The balance of power and the balance of terror. In P. Seabury (ed.), The balance of power. San Francisco: Chandler.

Unnever, J. \& Gabbidon, S. (2011). A theory of African American offending: race, racism and crime. New York: Routledge.

Van Klinken, G. (2007). Communal violence and democratization in Indonesia: small town wars. London: Routledge.

Vandewalle, D. (2012). After Qaddafi: the surprising success of the new Libya, Foreign Affairs, 91, $8-15$. 